\section{Tune Without a Piper}

Sir,--In "Tune Without a Piper" (Nature, 227, 113; 1970), your anonymous Washington Correspondent reported his views on the interactions of the scientific community with the Nixon Administration. I found his opinions for the most part thoughtful and valuable, but I must protest the gratuitous insult he levelled at my longtime friend and co-worker, Dr Lee A. DuBridge. $\mathrm{He}$ attributes much of Dr DuBridge's (alleged) inability to influence the Administration to the fact that DuBridge is "-too shy, even gauche-"." I am aware that British and American meanings of the same word may differ, and I do not have access to a British dictionary. The latest Webster's Dictionary defines "gauche" as "lacking in social graces or ease, tact and familiarity with polite usage: likely or inclined to commit social blunders, esp. from lack of experience or training"'.

The New Yorker once published a poem entitled "AntiTeller", describing a fictitious person in a distant nebula, all of whose characteristics were diametrically opposed to those of Edward Teller. I conclude that your correspondent has inadvertently described "Anti-DuBridge", rather than the gracious gentleman I have known so long as Lee DuBridge.

Yours faithfully,

Luis W. Alvarez

Lawrence Radiation Laboratory,

University of Caljfornia,

Berkeley, California, USA.

\section{Obituaries}

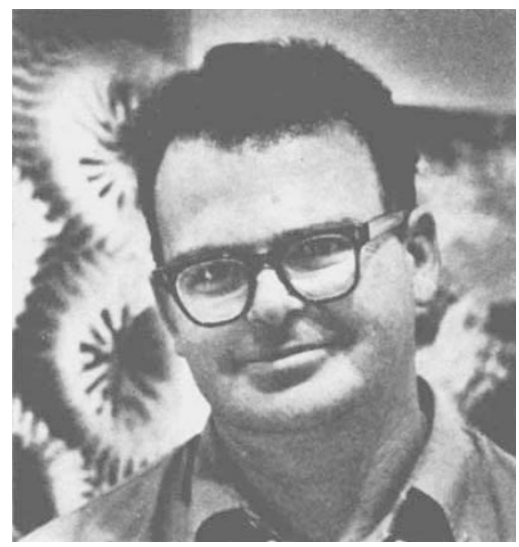

\section{Professor Thomas F. Goreau}

Tom Goreau, who died in New York on April 22, was born in Berlin in 1924. He had his elementary education in Munich but, with the advent of Hitler in 1933, his family left Germany to settle eventually in the United States in 1936. Goreau at first attended the High School of Music and Art in New York; after graduating BA at Clark University, Worcester, Massachusetts, in 1946, he proceeded for graduate work in physiology to Yale.

His professional contact with marine biology began in 1947 at the Scripps Institution and when, in 1951, he took up an appointment as lecturer in medical physiology in the then University College of the West Indies in Jamaica it was with the clear intention of studying coral reefs. There was little equipment, but he began work in a small boat with outboard motor and developed oxygen breathing apparatus which allowed him to explore the deeper regions of reefs before SCUBA was widely available.

He later became senior lecturer, then reader in comparative physiology and, in 1967, professor of marine science, being also appointed professor of biological sciences in the State University of New York at Stony Brook. He soon concentrated work on the reefs off the north coast which he revealed as probably the best developed of Atlantic formations, with a series of zones including massive buttresses and demanding comparison with the most complex Indo-Pacific reefs.

Aided by the Kaiser Bauxite Company, he acquired simple facilities at Discovery Bay, but the need for a suitably designed laboratory was clear and grants were eventually provided by the Wolfson Foundation and by Stony Brook. An admirably planned building, literally on the edge of reefs, was officially opened just one month before he died.

Goreau traced at first hand the differences in reef composition that come with depth. He showed how corals that grow as rounded masses in shallow water form flattened plates in greater depths; he distinguished between the primary reef framework, built essentially by corals and by calcareous algae, and the secondary deeper detrital formations. With radioactive tracers, applied in situ, he revealed the supreme significance of the symbiotic endozoic algae (zooxanthellae) in the added powers of calcification which distinguish reef-building from nonreef-building corals.

His work showed the West Indian coral fauna to be much richer in species than had been realized, and he was cooperating with Professor J. W. Wells of Cornell in a monograph to be published by the British Museum. With Dr Willard Hartman of Yale he was studying the nature of the stony sponges he had discovered in Jamaica and in the Pacific, for which they proposed a new class, Sclerospongiae. He found a uniquely adapted mytilid bivalve living symbiotically with fungid corals at Eilat and elsewhere in the northern regions of the Red Sea. His interests also extended into the Pacific where he had worked at Eniwetok in 1957 and later, with the Belgian De Moor Expedition, on the Great Barrier Reef and, most recently, at Guam and Saipan in Micronesia.

\section{Announcements}

\section{University News}

A chair of ehildren's dentistry and orthodontics has been established in the Department of Dental Health, University of Birmingham, and will be held by Mr T. D. Foster.

Mr L. F. Finkelstein has been appointed professor of instrument and control engineering in the Department of Automation Engineering at The City University. Professor D. V. Lindley, University College, London, and Dr J. R. Tillman, deputy director of research at the Post Office Telecommunications Headquarters, have been appointed visiting professors in The City University, in the Departments of Mathematics and of Electrical and Electronic Engineering, respectively. The following visiting professors have been reappointed: Sir Robert Shone, in the Graduate Business Centre; Professor L. E. Prosser, director of the British Hydromechanics Research Association; Professor R. E. Rowe, director of research and development at the Cement and Concrete Association; and Professor W. H. Ward, head of the Geotechnies Division at the Building Research Station, all in the Department of Civil Engineering. 